\title{
Reduksi minyak, lemak, dan bahan organik limbah rumah makan menggunakan grease trap termodifikasi karbon aktif
}

\author{
T. A. Zaharah ${ }^{1 *}$, Nurlina ${ }^{1}$, R. R. E. Moelyani ${ }^{2}$ \\ ${ }^{1}$ Jurusan Kimia, FMIPA, Universitas Tanjungpura, Pontianak, Indonesia \\ 2Jurusan Teknik Sipil, Fakultas Teknik, Universitas Tanjungpura, Pontianak, Indonesia
}

\begin{abstract}
Abstrak
Minyak dan lemak termasuk dalam kategori limbah organik yang dapat mencemari lingkungan. Grease trap dapat memisahkan minyak dan lemak dari limbah, sehingga tidak menggumpal dan membeku yang dapat membuat pipa tersumbat. Pada penelitian ini, grease trap dimodifikasi dengan karbon aktif. Penelitian ini bertujuan untuk mengkaji efisiensi penggunaan grease trap yang dimodifikasi dengan karbon aktif untuk mereduksi minyak, lemak dan bahan organik dari limbah rumah makan. Penelitian ini dimulai dari preparasi karbon aktif, kemudian dilanjutkan ke tahapan persiapan alat, optimasi alat dan uji kinerja alat grease trap termodifikasi karbon aktif. Berdasarkan hasil pengujian, air limbah hasil output dari grease trap mengandung 1217,6 mg/L COD; $645 \mathrm{mg} / \mathrm{L}$ BOD; $156 \mathrm{mg} / \mathrm{L}$ TSS; dan 88,45 mg/L minyak dan lemak. Kandungan air limbah hasil output grease trap yang dimodifikasi dengan kolom sepanjang $10 \mathrm{~cm}$ yang berisi karbon aktif adalah COD 2,5 mg/L; BOD $19 \mathrm{mg} / \mathrm{L}$; TSS 3,4 $\mathrm{mg} / \mathrm{L}$; minyak dan lemak tidak terdeteksi. Penggunaan kolom yang diisi dengan karbon aktif untuk dimodifikasi pada alat grease trap ternyata mampu menurunkan konsentrasi BOD, COD, TSS, minyak dan lemak dari limbah hingga ke nilai baku mutu air limbah bagi usaha dan/atau kegiatan domestik.
\end{abstract}

\begin{abstract}
.
Oil and grease are organic wastes that can cause environmental problems. Grease trap is a simple technology for trapping oils and grease in waste. In this study, the grease trap was modified with activated carbon. This study aimed to examine the optimum conditions and efficiency of the use of grease trap modified with activated carbon to reduce oils, grease and organic waste from restaurant. The first step of procedure was preparation of activated carbon, then preparation of grease trap, optimization and performance test of grease trap modified activated carbon. Based on the test results, the waste water output from grease trap contained $1217.6 \mathrm{mg} / \mathrm{L}$ COD; $645 \mathrm{mg} / \mathrm{L} \mathrm{BOD;} 156 \mathrm{mg} / \mathrm{L} \mathrm{TSS}$; and $88.45 \mathrm{mg} / \mathrm{L}$ of oils and grease. The waste water output from grease trap modified with $10 \mathrm{~cm}$ column containing activated carbon contained $2.5 \mathrm{mg} / \mathrm{L} ; B O D 19 \mathrm{mg} / \mathrm{L} ; \mathrm{TSS} 3.4$ $\mathrm{mg} / \mathrm{L}$; oil and grease was not detected. The use of activated carbon column to modify the grease trap was able to reduce the concentration of BOD, COD, TSS, oil and grease up to the value permitted according to waste water quality standard for domestic activity.
\end{abstract}

Keywords: $B O D, C O D$, grease trap, grease, oil

Kata kunci: BOD, COD, grease trap, lemak, minyak

\section{PENDAHULUAN}

Minyak, lemak dan bahan organik merupakan parameter baku mutu air limbah bagi berbagai jenis usaha dan/atau kegiatan industri, perhotelan, fasilitas pelayanan kesehatan, rumah pemotongan hewan, maupun limbah domestik. Limbah domestik meliputi limbah kawasan pemukiman, kawasan perkantoran, kawasan perniagaan, dan apartemen; rumah makan; dan asrama. Menurut Peraturan Menteri Lingkungan Hidup Republik Indonesia Nomor 5 tahun 2014 tentang baku mutu air limbah bagi usaha dan/atau kegiatan, Lampiran XLVI, limbah domestik harus memiliki kriteria kadar BOD dan TSS maksimum 100 $\mathrm{mg} / \mathrm{L}$, kadar minyak dan lemak maksimum adalah $10 \mathrm{mg} / \mathrm{L}$.

\footnotetext{
${ }^{*}$ Korespondensi Penulis

Email : titinanita@pplh-untan.or.id
} 
Limbah minyak dan lemak termasuk dalam kategori limbah organik yang dapat menyebabkan masalah lingkungan seperti akumulasi pada pipa sehingga menyebabkan sumbatan (Islam et al. 2013), berbahaya bagi kehidupan di perairan (Manahan 2009) dan dapat berpotensi menyebabkan mutagenik dan karsinogenik pada manusia (Lan et al. 2009). Limbah bahan organik di perairan dapat berasal dari makanan yang dibuang ke badan air, detergen, plastik, dan lain-lain. Meskipun bahan organik ini ada yang bersifat biodegradable, namun keberadaan bahan biodegradable dalam jumlah banyak di dalam air dapat membahayakan kehidupan organisme di air. Hal tersebut dapat terjadi karena mikroorganisme akan membutuhkan oksigen terlarut dalam jumlah yang banyak untuk mendegradasi bahan organik tersebut, sehingga pasokan oksigen terlarut di air yang dibutuhkan bagi kehidupan perairan menjadi berkurang. Akibatnya ikan-ikan akan mati, timbul bau tidak sedap, dan secara keseluruhan akan menurunkan kualitas perairan (National Small Flows Clearinghouse 1997).

Jumlah oksigen yang dibutuhkan untuk mendegradasi bahan organik di perairan disebut dengan biochemical oxygen demand (BOD). BOD merupakan salah satu parameter penting untuk menentukan dan mengevaluasi kualitas perairan (Revelli dan Ridolfi 2004).

Pengolahan limbah merupakan hal yang mutlak dilakukan agar limbah yang dibuang dapat memenuhi kriteria baku mutu limbah. Bagi usaha rumah makan berskala kecil dan menengah seperti rumah makan dengan luas bangunan kurang dari $1000 \mathrm{~m}^{2}$, memang belum memiliki kewajiban untuk menyusun dokumen Analisis Mengenai Dampak Lingkungan (AMDAL) dan dokumen Upaya Pengelolaan Lingkungan Hidup (UKL) Upaya Pemantauan Lingkungan Hidup (UPL). Namun usaha dan/atau kegiatan kecil dan menengah tersebut tetap harus memiliki pengelolaan limbah yang baik agar mereka layak mendapatkan izin usaha dan/atau kegiatan yang mempersyaratkan mereka melakukan pengelolaan limbah yang dikenal dengan Dokumen Pengelolaan Lingkungan Hidup (DPLH). Dokumen ini nantinya akan dikeluarkan oleh Badan Lingkungan Hidup Kota/Provinsi.

Dokumen ini merupakan salah satu syarat keberlangsungan usaha rumah makan berskala kecil dan menengah. Masalah utama yang dihadapi oleh usaha dan/atau kegiatan kecil dan menengah adalah kesulitan mereka untuk membuat pengolahan limbah yang sederhana, murah dan mudah diaplikasikan. Oleh karena itu pada penelitian ini, peneliti bermaksud mengakomodir hal tersebut agar para pengusaha usaha kegiatan kecil dan menengah dapat memiliki pengolahan limbah, terutama limbah minyak, lemak dan bahan organik.

Pengolahan limbah yang dapat diaplikasikan secara sederhana adalah grease trap. Grease trap merupakan alat yang telah cukup dikenal sebagai pretreatment. Alat ini merupakan alat penahan minyak dan lemak dan 
mencegahnya sampai ke tempat pembuangan limbah. Penahan beroperasi dengan menggunakan sejumlah ruang penyekat untuk memperlambat aliran limbah saat melintasi alat ini. Ruang-ruang tersebut memaksimalkan waktu retensi air limbah sehingga memungkinkan padatan yang mengendap pada bagian bawah perangkap, sedangkan minyak dan lemak terkoagulasi dengan air dan mengambang ke permukaan sehingga mudah untuk dipisahkan (Kosciuzko National Park 2012). Alat ini membantu untuk memisahkan minyak dari air, sehingga minyak tidak menggumpal dan membeku di pipa pembuangan dan membuat pipa tersumbat.

Pada penelitian ini, grease trap dikombinasikan dengan adsorben karbon aktif, sehingga dapat meningkatkan kinerja grease trap. Penelitian sebelumnya yang telah dilakukan oleh Gawad (2014) telah melakukan penghilangan minyak menggunakan zeolit dengan efisiensi hingga 80\%. Grease trap yang dikombinasikan dengan karbon aktif dioptimasi sehingga diharapkan dapat meningkatkan kinerja grease trap yang tidak hanya dapat mereduksi minyak dan lemak, tapi juga mereduksi bahan organik yang terkandung pada limbah. Penelitian ini bertujuan untuk mengkaji kondisi optimum dan efisiensi penggunaan grease trap yang dimodifikasikan dengan karbon aktif untuk mereduksi minyak, lemak dan bahan organik dari limbah rumah makan. Teknologi grease trap yang dimodifikasikan dengan karbon aktif diharapkan dapat menjadi solusi praktis bagi penanganan limbah minyak, lemak dan bahan organik. Manfaat penelitian ini adalah penggunaan grease trap bagi usaha rumah makan berskala kecil dan menengah.

\section{METODOLOGI}

\subsection{Lokasi kajian dan waktu penelitian}

Penelitian ini dilaksanakan di Laboratorium Kimia Fakultas Matematika dan Ilmu Pengetahuan Alam, Universitas Tanjungpura, Pontianak. Penelitian dilaksanakan pada bulan September s/d November 2016.

\subsection{Alat dan bahan} Tabel 1.

Alat dan bahan yang digunakan dalam penelitian ini ditunjukkan pada

Tabel 1. Alat dan bahan yang digunakan dalam penelitian.

\begin{tabular}{lll}
\hline \multicolumn{2}{c}{ Alat } & \multicolumn{1}{c}{ Bahan } \\
\hline - Ayakan 100 mesh, bulb, & - & Limbah cair lemak dan minyak dari rumah makan berskala \\
- Desikator berisi silika & & kecil di Kota Pontianak. \\
gel, & - & Karbon aktif komersil, \\
- DO meter, & - & Bahan kimia: asam klorida; pelarut organik berupa $n$ - \\
- Evaporator, & heksana, methyl tert buthyl ether (MTBE); padatan \\
\hline
\end{tabular}




\begin{tabular}{ll}
\hline \multicolumn{1}{c}{ Alat } & \multicolumn{1}{c}{ Bahan } \\
\hline - Kolom kromatografi, & natrium sulfat anhidrat; air destilasi; larutan buffer fosfat, \\
- magnetic stirrer, & larutan magnesium sulfat; larutan kalsium klorida; larutan \\
- neraca analitik, & feri klorida; larutan asam sulfat; kertas Whatman Grade \\
- oven, & 934 AH dengan ukuran pori (particle Retention) $1,5 \mu \mathrm{m}$ \\
- pH-meter digital, & (standar untuk analisis TSS di air); Gelman type A/E, \\
- penangas air, & dengan ukuran pori (particle retention) 1,0 $\mu$ m (standar \\
- peralatan gelas standar & filter untuk pengecekan TSS/TDS pada prosedur analisis \\
- pipa PVC, & air sanitari), E-D Scientific Specialities grade 161 (VWR \\
- pompa vakum, & brand grade 161) dengan ukuran pori (particle retention) \\
- shaker, & 1,1 $\mu$ m (rekomendasi untuk penggunaan pengecekan \\
spektrofotometer UV-Vis & TSS/TDS pada air dan air limbah); larutan kalium \\
& dikromat; larutan asam sulfat-perak sulfat; larutan \\
& indikator ferroin; larutan ferro ammonium sulfat; larutan \\
& baku potassium hidrogen phthalate; asam sulfanamat; dan \\
\hline
\end{tabular}

\subsection{Prosedur kerja atau tahapan penelitian}

Preparasi karbon aktif. Karbon aktif yang telah diperoleh diambil $500 \mathrm{~g}$ dan direndam dalam $\mathrm{HCl}$ 4M sebanyak $250 \mathrm{~mL}$ selama 24 jam. Kemudian disaring dan dicuci dengan aquades sampai $\mathrm{pH}$ netral, langkah selanjutnya residu dikeringkan dalam oven pada suhu $110^{\circ} \mathrm{C}$ selama 3 jam.
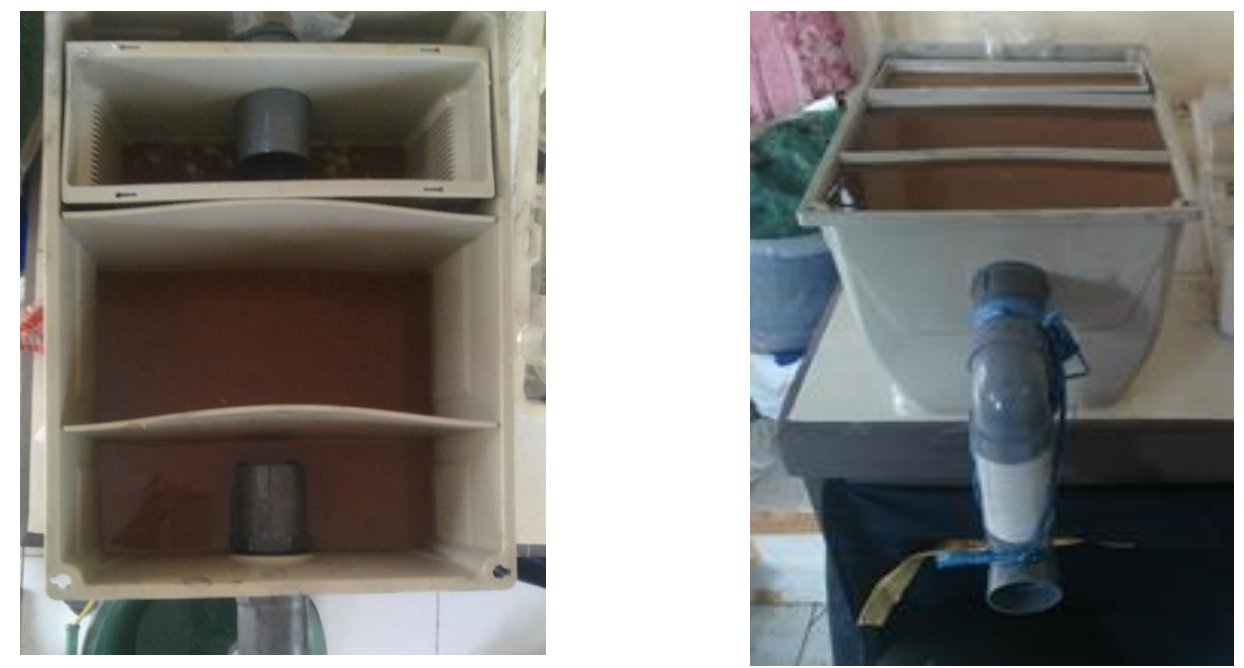

Gambar 1. Grease trap tanpa modifikasi (kiri), pipa pembuangan langsung mengarah ke penampungan (kiri), grease trap termodifikasi karbon aktif (kanan).

Arang yang telah dieluarkan dari oven, kemudian dimasukkan ke dalam desikator (Karthikeyan et al. 2008). Persiapan alat grease trap yang dimodifikasi dengan karbon aktif. Alat grease trap disiapkan kemudian dilakukan modifikasi dengan karbon aktif. Karbon aktif diisikan ke dalam pipa PVC sepanjang $20 \mathrm{~cm}$. 
Limbah minyak dan lemak kembali dimasukkan ke grease trap, kemudian melewati kolom pipa PVC yang berisi karbon aktif, selanjutnya ditampung dalam wadah (Gambar 1).

\subsection{Uji kinerja alat grease trap yang dimodifikasi dengan karbon aktif}

a. Uji minyak dan lemak

Uji minyak dan lemak merujuk pada SNI 06-6989.10-2004 Bagian 10: Cara Uji Minyak dan Lemak. Kandungan parameter minyak dan lemak dianalisis dengan metode ekstraksi gravimetri. Hasil analisis kandungan parameter minyak dan lemak dari sampel yang diperiksa, dipilih nilai konsentrasi yang tertinggi sebagai dasar pembuatan larutan artifisial.

b. Uji Biochemical Oxygen Demand (BOD)

Uji BOD merujuk pada SNI.6989.72: 2009 Tentang Air dan Air LimbahBagian 72: Cara Uji Kebutuhan Oksigen Biokimia (Biochemical Oxygen Demand/ BOD).

c. Uji total suspended solid (TSS)

Uji TSS merujuk pada SNI 06-6989.3-2004 Air dan air limbah- Bagian 3: Cara Uji Padatan Tersuspensi Total (Total Suspended Solid/TSS) secara Gravimetri.

\section{HASIL DAN PEMBAHASAN}

Karbon aktif komersial yang telah dipreparasi, diaplikasikan pada grease trap. Grease trap memiliki ruang penyekat yang bertujuan memisahkan minyak dan lemak dari air limbah rumah makan. Grease trap terdiri dari 3 bagian kolom (2 sekat). Kolom pertama berisi saringan yang bertujuan untuk memisahkan padatan (baik berupa TSS maupun pengotor padatan lainnya yang terkandung pada air limbah). Air limbah yang dapat melewati saringan dan masuk ke kolom kedua. Pada kolom ini akan terjadi proses pemisahan minyak dan lemak yang terkandung pada air limbah. Minyak dan lemak memiliki massa jenis yang lebih ringan daripada air (massa jenis minyak adalah $0,8 \mathrm{~g} / \mathrm{cm}^{3}$, massa jenis lemak 0,8$0,9 \mathrm{~g} / \mathrm{cm}^{3}$, dan massa jenis air adalah $1 \mathrm{~g} / \mathrm{cm}^{3}$ ), sehingga akan memisah dan mengambang di atas, sedangkan air limbah dapat lewat ke bagian tiga melalui bagian bawah grease trap. Pada bagian ketiga air yang sudah direduksi TSS serta minyak dan lemaknya kemudian akan dikeluarkan ke pembuangan melalui keran yang terpasang pada kolom ketiga.

Hasil uji kandungan minyak dan lemak serta bahan organik pada air limbah hasil output dari grease trap menunjukkan bahwa kadar BOD, TSS, minyak dan lemak yang terkandung dalam air limbah masih melewati nilai baku mutu 
menurut Peraturan Menteri Lingkungan Hidup Republik Indonesia Nomor 5 tahun 2014 tentang baku mutu air limbah bagi usaha dan/ atau kegiatan, baku limbah domestik (Tabel 2). Hasil tersebut menunjukkan bahwa meskipun sudah menggunakan grease trap, ternyata masih ada minyak dan lemak yang tidak dapat tertahan dengan baik di grease trap atau tetap dapat melewati saringan grease trap, kemudian keluar sebagai air limbah. Secara prinsip kerja alat, grease trap memang bukan merupakan alat yang dapat mereduksi bahan organik, sehingga nilai BOD (mewakili konsentrasi bahan organik secara umum) dari air limbah hasil output dari grease trap masih di atas baku mutu.

Tabel 2. Kandungan air limbah hasil output dari grease trap.

\begin{tabular}{ccccc}
\hline Parameter Uji & Satuan & Air Limbah & $\begin{array}{c}\text { Air Limbah Hasil } \\
\text { Output dari Grease trap }\end{array}$ & Baku mutu* \\
\hline COD & $\mathrm{mg} / \mathrm{L}$ & & 1217,6 & - \\
BOD & $\mathrm{mg} / \mathrm{L}$ & & 645 & 100 \\
TSS & $\mathrm{mg} / \mathrm{L}$ & & 156 & 100 \\
$\begin{array}{c}\text { Minyak dan } \\
\text { lemak }\end{array}$ & $\mathrm{mg} / \mathrm{L}$ & 527 & 88,45 & 10 \\
\hline
\end{tabular}

*Peraturan Menteri Lingkungan Hidup Republik Indonesia Nomor 5 tahun 2014 tentang baku mutu air limbah bagi usaha dan/atau kegiatan, baku limbah domestik, Lampiran XLVI

Limbah minyak dan lemak setelah melewati grease trap, dilewatkan kembali pada kolom yang berisi karbon aktif, kemudian hasil output minyak dan lemak tersebut ditampung ke dalam wadah (Gambar 1). Ketika melewati pipa PVC yang berisi karbon aktif, bahan organik dari minyak dan lemak direduksi berdasarkan prinsip adsorpsi. Adsorpsi bahan organik, TSS, minyak dan lemak oleh karbon aktif terjadi karena pori yang dimiliki oleh adsorben. Karbon aktif akan melakukan kontak dengan bahan pencemar, dimana karbon aktif akan mengadsorpsi molekul bahan pencemar hingga tercapai kondisi setimbang. Menurut Wijaya et al. (2002), waktu kontak merupakan suatu hal yang sangat menentukan dalam proses adsorbsi. Waktu kontak yang lebih lama memungkinkan proses difusi dan penempelan molekul adsorbat berlangsung lebih baik. Konsentrasi zat-zat organik akan turun apabila waktu kontaknya cukup.

Hasil pengujian konsentrasi COD, BOD, TSS, minyak dan lemak dari limbah minyak dan lemak yang dilewatkan pada grease trap yang dimodifiaksi karbon aktif dapat dilihat pada Tabel 3. Adsorpsi yang terjadi yakni akibat adanya medan gaya pada permukaan adsorben (karbon aktif) yang menarik molekulmolekul adsorbant (limbah cair). Pada proses ini, partikel atau molekul bahan pencemar akan menempel pada permukaan karbon aktif dan arang aktif karbon aktif yang disebabkan adanya perbedaan muatan yang lemah diantara keduanya yang disebabkan oleh gaya van der Waals. Tarik menarik akan terjadi antara 
muatan positif dari karbon aktif dan gugus karboksil yang bermuatan negatif pada bahan pencemar, sehingga membentuk suatu lapisan tipis partikel-partikel halus pada permukaan karbon aktif.

Tabel 3. Kandungan air limbah hasil output dari grease trap yang dimodifikasi dengan kolom yang berisi adsorben karbon aktif dan karbon aktif.

\begin{tabular}{ccccc}
\hline $\begin{array}{c}\text { Parameter } \\
\text { Uji }\end{array}$ & Satuan & $\begin{array}{c}\text { Air Limbah } \\
\text { Hasil Output } \\
\text { dari Grease trap }\end{array}$ & $\begin{array}{c}\text { Air Limbah Hasil Output dari } \\
\text { Grease trap yang Dimodifikasi } \\
\text { dengan Kolom yang Berisi } \\
\text { Adsorben Karbon Aktif }\end{array}$ & $\begin{array}{c}\text { Baku } \\
\text { mutu* }\end{array}$ \\
\hline COD & $\mathrm{mg} / \mathrm{L}$ & $1.217,6$ & 2,5 & - \\
BOD & $\mathrm{mg} / \mathrm{L}$ & 645 & 19 & 100 \\
TSS & $\mathrm{mg} / \mathrm{L}$ & 156 & 3,4 & 100 \\
$\begin{array}{c}\text { Minyak dan } \\
\text { lemak }\end{array}$ & $\mathrm{mg} / \mathrm{L}$ & 88,45 & - & 10 \\
\hline $\begin{array}{l}\text { *Peraturan Menteri Lingkungan Hidup Republik Indonesia Nomor } 5 \text { tahun 2014 tentang baku mutu air limbah bagi } \\
\text { usaha dan/ atau kegiatan, baku limbah domestik, Lampiran XLVI }\end{array}$
\end{tabular}

\section{KESIMPULAN DAN SARAN}

Berdasarkan penelitian yang telah dilakukan dapat disimpulkan bahwa penggunaan grease trap sebagai solusi menurunkan konsentrasi minyak dan lemak dari air limbah memang telah terbukti, namun ternyata belum cukup mampu menurunkan konsentrasi bahan organik, TSS, minyak dan lemak hingga ke nilai baku mutu menurut Peraturan Menteri Lingkungan Hidup Republik Indonesia Nomor 5 tahun 2014 tentang baku mutu air limbah bagi usaha dan/ atau kegiatan, baku limbah domestik, Lampiran XLVI. Penggunaan kolom yang diisi dengan karbon aktif untuk dimodifikasi pada alat grease trap ternyata mampu menurunkan konsentrasi bahan organik, TSS, minyak dan lemak lebih baik sehingga konsentrasi bahan organik, TSS, minyak dan lemak air limbah keluaran dari grease trap yang dimodifikasi dengan karbon aktif jauh lebih rendah dari baku mutu.

\section{Ucapan terima kasih}

Terima kasih kepada Universitas Tanjungpura yang telah memfasilitasi penelitian ini melalui dana hibah fundamental aplikatif Universitas Tanjungpura.

\section{Daftar Pustaka}

Gawad HSA. 2014. Oil and grease removal from industrial wastewater using new utility approach. Advances in Environmental Chemistry 2014(6).

Islam MS, Saiful, Hossain M, Sikder M and Morshed M. 2013. Acute toxicity of the mixtures of grease and engine wash oil on fish, pangasius sutch, under 
laboratory condition. Biotechnology and Pharmacology Research 2(1):306-317.

Karthikeyan S, Sivakumar P and Palanisamy PN. 2008. Novel activated carbons from agricultural wastes and their characterization. E-Journal of Chemistry 5:409-426.

Kosciuzko National Park. 2012. Wastewater pre-treatment. The Office of Environment and Heritage. Sydney.

Lan WU, Gang GE and Jinbao WAN. 2009. Biodegradation of oil wastewater by free and immobilized Yarrowia lipolytica W29. Journal of Environmental Sciences 21(2):237-242.

Manahan SE. 2009. Environmental Chemistry. 9th edition. GRC Press LLC. Florida.

National Small Flows Clearinghouse. 1997. Basic wastewater characteristics. Pipeline 8(4):1-8.

Peraturan Menteri Lingkungan Hidup Republik Indonesia Nomor 5 Tahun 2014 Tentang Baku Mutu Air Limbah.

Revelli R and Ridolfi L. 2004. Stochastic dynamics of BOD in a stream with random inputs. Advances in Water Resources 27(9):943-952.

Wijaya K, Tahir I dan Baikuni A. 2002. Sintesis lempung terpilar $\mathrm{Cr}_{2} \mathrm{O}_{3}$ dan pemanfaatannya sebagai inang senyawa p-nitroanalin. Indonesian Journal of Chemistry 2(1):12-21. 